\title{
WRITTEN WORD OF PAVLE M. VUJEVIĆ
}

\author{
Stevan Stanković ${ }^{1}$ \\ *University of Belgrade, Faculty of Geography, Studentski trg 3/III, 11000 Belgrade, \\ Serbia
}

Abstract: After completing Serbian Orthodox Gimnasium in 1889, in Novi Sad, Pavle M. Vujević, he has been studied geography in Vienna, where in 1904 he defended doctoral disertation. He improved his knowledge in climarology and meteorology in Berlin and Postdam. For full professor of University of Belgrade he was scelected in 1921. He has written more than 150 scientific articles from climatology, meteorology, hydrology and geography.

Key words: Pavle M. Vujević, geography, climatology, meteorology, potamology, variation climate, bioclimatic elements, climatological statistics.

\section{A student of famous professors from Vienna}

Among our famous geographers of the past, Pavle M. Vujević, one of the closest and most loyal associates of Jovan Cvijić, a corresponding and regular member of the Serbian Academy of Sciences and Arts, recognizable in international scientific institutions as a climatologist and meteorologist of world importance, author of extensive scientific studies and university textbooks.

Pavle M. Vujevićwas born in Ruma on August 22,1881. After graduating from the Serbian Orthodox Gimnasium in Novi Sad, he went to Vienna where he completed his studies studying geography, geology, physics, climatology, and meteorology and hung out with Milutin Milanković (1879-1958), then a student and doctoral student in technical sciences.

In Vienna, under the mentorship of renowned scholars Albrecht Penck (1858-1945), Eduard Suiss (1831-1914), Julius von Hann (1839-1921)

1 Corresponding author: S. Stanković, University of Belgrade, Faculty of Geography, Studentski trg 3/III, 11000 Belgrade, Serbia; e-mail: geofiz40@gmail.com 
and Wilhelm Tomaschek, 1841-1901), in 1904 he defended his doctoral dissertation entitled Tisa, a potamological study, which was published in Leipzig in 1906, when the author was 23 years old. In the doctoral dissertation of Pavle M. Vujević analyzed the flows of the Tisza River in different seasons from the most upstream part of the river to its confluence with the Danube. By constructing an isohiet map of the basin, according to data from 244 rain gauge stations and flow data, he determined the water balance of the basin (for the period 1891-1900), an equation that is often attributed to his mentor in the professional literature. With four new equations, Vujević determines the flows on the Tisza as a function of precipitation, which practically means that with each annual amount of precipitation, the runoff, ie the flow, can be determined. Vujević explains the frequent coincidence of high waters and the formation of flood waves on the Tisza by the regime and intensity of precipitation, the topography of the terrain and the shape of the upper and middle course basins. The chapter in which the erosive and accumulative processes in the riverbed and the meander's bed are discussed is especially important, the evolution of which is explained on a mathematically based theory (Rakićević, 1998). To determine the flow of the Tisza River, he used four mathematical equations and precipitation data in a basin with 244 rain gauge stations. This book is considered a classic work in the domain of potamology - the science of rivers and is therefore often cited in hydrological studies and textbooks. It was the first permanently significant scientific contribution of Vujević to modern science. He determined the relations between precipitation, runoff and evaporation, which is of special importance for knowing the water balance and the possibility of rational use of water of a large plain river, known for its fairly large basin. He treated the flow of the Tisza through four equations as a function of precipitation, which is important for knowing erosion, accumulation of materials and conditions for the formation of flood waves. After defending his dissertation and publishing a book about the Tisza, Pavle M. Vujević was very interested in hydrology, and over time, in the field of this science, he published several articles (Hydrography of the Kingdom of Yugoslavia, Hydrography of Yugoslavia, Hydrography and Climate of Vojvodina, Danube, Rivers and Lakes of Yugoslavia, Hydrological characteristics of rivers in Serbia, Climate and hydrography of Yugoslavia, Hydrographic conditions of Yugoslav waters). In addition to hydrology, he was even more successful in climatology and meteorology and went deep into the domain of mathematical geography and climatological statistics. Scientific articles, extensive monographs and university textbooks from the mentioned disciplines are still cited today. 


\section{Scientific training in Berlin and Potsdam}

After defending his doctoral dissertation, in 1904 and 1905, Vujević continued his professional development at the Prussian Meteorological Institute in Berlin, as well as at the Meteorological Observatory in Pastdam. There he met and collaborated with the famous German meteorologists Wilhelm von Becold and Gustav Hellmann, under the supervision of Jovan Cvijić, when, starting in 1902, he regularly informed about his work. He returned to Novi Sad from Germany. As one of the Serbs, educated in Vienna, he felt a moral obligation to give his knowledge to his home country - Serbia. At the urging of Cvijić, on the recommendation of Albrecht Penck, in March 1907 he was elected assistant professor of climatology and meteorology, the University of Belgrade was founded in 1905 and was very useful in building the Department of Geography, headed by Cvijić, as well as in preparatory actions for the establishment of the Serbian Geographical Society. To the students of geography of the then Faculty of Philosophy, University of Belgrade, Vujević taught mathematical geography, general climatology, dynamic meteorology. In addition, he held special courses on weather and weather forecasting, the climate of the Balkan Peninsula, climate and man, dynamic meteorology and water circulation in nature. From the election for assistant professor (1907), associate professor (1919) and full professor (1921), until 1941, he was the only university professor of climatology and meteorology in Belgrade and Serbia.

\section{Geographical Society and its Glasnik}

In 1910, Pavle M. Vujević participated in the founding of the Serbian Geographical Society, where he was elected its secretary and together with Jovan Cvijić (1865-1927), edited I, III-IV, V, VI, VII-VIII volumes of the Glasnik of the Serbian Geographical Society, which was printed at the suggestion of Jovan Cvijić from 1928 to 1948 as the Glasnik of the Geographical Society. The original name was returned to him in 1948, and as such it remains.

Glasnik Srpskog geografskog drustva, po reci profesora Borivoja Z. Milojević, the bed of the late Jovan Cvijic is especially close to his heart: his famous studies give great value to every issue of Glasnik; there is not a single issue of Glasnik, and there is not a single, almost not the smallest work, published in Glasnik, on which Cvijić's clever gaze did not stay, he was seriously ill, he took care of Glasnik, which was being reprinted. 
Continuing the work of Cvijić, Pavle M. Vujević approached Glasnik with utmost sincerity and demanded from his associates to check once and again everything they wrote, especially the tables of statistical data, which are the basis for analyzes and conclusions. Loyal to the Serbian Geographical Society and its Glasnik, Pavle M. Vujević published several different works, reviews, notes on the pages of the periodical geographical publication on the Balkan Peninsula, analyzed statistical data and wrote obituaries in memory of his predecessors. From Glasnik, we especially single out an extensive study on the climate of the island of Hvar, which brought him the title of honorary citizen of the town of Hvar, Vujević was the president of the Serbian Geographical Society in three election terms: 1931-1933, 1947-1955 and 1956-1959.

He was especially engaged in organizing the Third Congress of Slavic Geographers and Ethnographers, which was held in 1930 in Belgrade. He edited the publications from the mentioned congress: Kingdom of Yugoslavia, geographical and ethnographic review, page 167, editions in Serbian and French and Description of the path of Slavic geographers and ethnographers, first and second part, a total of 371 pages. In addition, he is known as a long-term editor of the Report of the Meteorological Observatory in Belgrade, that is, the Proceedings of the Geographical Institute Jovan Cvijic of the Serbian Academy of Sciences and Arts and its Special Editions. In 1954, he was proclaimed the lifelong, and to this day the only, honorary president of the Serbian Geographical Society.

\section{Unrepeatable war sufferings}

Pavle M. Vujević was a quiet, honest and overworked man and scientist, who enjoyed great respect from his students and associates in the country and abroad. The second decade of the 19th century, when Serbia was affected by great war events, fell hard on him, because it separated him from everyday teaching and research work. He took part in the Balkan wars and the First World War. As a soldier, he crossed the Albanian mountains and arrived in Corfu, severely physically and mentally ill. Although the General Department of the Supreme Command approved his departure for treatment in San Giovanni, he did not board the ship, probably because there were more serious patients. After the end of the Great War, he was sent to London, where he worked on collecting aid within the Red Cross. Upon his return to Belgrade, on June 21, 1919, he determined that the manuscripts he 
had been working on for years had disappeared in the bombing and looting. In two letters to Jovan Cvijić, who was still in Paris, he informed that he had visited his house and wrote the following: The library is in good condition, but it seems that something has been reduced. They didn't leave me a single letter. They tore out my atlases. The mass of the houses remained the same as after the bombing. The world will not repair houses; the government is requiring private apartments. My apartment was requisitioned by the Ministry of Food. They barely allowed me to bring out at least my books. I couldn't take anything from things. Among the books I found all my lectures. At least that saved my 15-year work. The temperature tables of the Kingdom of Serbia and the manuscript were taken to me. I worked on that for two full years in the basement of the Observatory, and all that work failed. I have nothing left of the manuscript. Most of the books I procured after the Bulgarian war were taken away. I lost all the dictionaries, all the atlases, all the maps, except for a few 1: 75,000. He was engaged in the renewal of the Geographical Institute and the University, of which he was rector 1919-1920.

Jovan Cvijić and the establishment of meteorological stations in Serbia, Macedonia and Montenegro. During 1919, he helped Jovan Cvijić at the Peace Conference in Paris. He spent some time at the head of the Meteorological Observatory in Belgrade, lectured at the Faculty of Agriculture in Zemun, the Faculty of Agriculture in Novi Sad, and lectured in Cambridge and Aberdeen. He could do all that because he was a modernly educated scientist, who studied not only geography, but also geology, physics, meteorology and climatology, and was in contact with Albrecht Penck, as well as with Jovan Cvijić and Milutin Milanković (1879-1958).

\section{Hanging out with Milutin Milanković}

Pavle Vujević was friends with Milutin Milanković, who at that time was intensively dealing with the theoretical foundations of climate. It can be assumed that there was Milanković's influence on Vujević: Vujević tried to look at the climate of the Balkans for a longer period (Opra, 1997). In that sense, the year 1931 is significant, when Vujević in Paris, published the work Historical documents on climate variations in the territory of the Kingdom of Yugoslavia and surrounding areas. The work has 55 pages with 300 records on time and climate between 1358 and 1864. He made records based on insights into the books of Orthodox monasteries and churches, but also from books in Turkish and Latin. Vujević organized teaching courses in 
which he interpreted the overall knowledge about the circular movement of water in nature, dynamic meteorology, climate and man, weather, weather forecast and the climate of the Balkan Peninsula. From 1947 to 1955 he was the head of the Department of Meteorology at the Faculty of Natural Sciences and Mathematics in Belgrade, and from 1957 to 1961 the head of the Geographical Institute Jovan Cvijić of the Serbian Academy of Sciences and Arts. For several years, he was elected Director of the Meteorological and Climatological Institute of Serbia. He was the representative of Yugoslavia in the European section of the World Meteorological Organization and the president of the National Commission for the International Geophysical Union at the Academic Council of Yugoslavia (1955).

\section{Recognitions and work in international organizations}

Over time, Pavle Vujević was elected a corresponding member of the Czechoslovak Geographical Society of Prague in 1926 (Ceskoslovenská Spolecnost Zemlepisná), the Geographical Society of Berlin in 1928 (Gesellschaft für Ergkunde zu Berlin), an honorary member of the Czechoslovak Geographical Society of Prague in 1931 (Ceskoslovenskén ), a corresponding member of the Bulgarian Geographical Society from Sofia in 1935 (Bulgarian Geographical Society), the Hungarian Meteorological Society in 1940 (Magyar Meteorolgiai Tarsaság), the Geographical Society of Croatia (1961). He was elected an honorary doctor of the University of Vienna in 1954, the Meteorological Society of Serbia and the Geographical Society of Berlin. In 1960, he received the Lifetime Achievement Award given by the Commission of the Council for Scientific Work of the Socialist Republic of Serbia, for special achievements in the field of science, as well as the Jovan Cvijić Medal. He is the holder of the Albanian Monument, the Order of Saint Sava, the Order of Labor of the First Order, and the Seventh of July Award of the Government of Serbia. Due to the high scientific reach, the Senate of the University of Vienna in 1954, the doctoral dissertation of Pavle M. Vujević, included in the category of golden doctorates. Vujević participated in the work of the International Commission for the Study of Climate Change, for which he used the terms climate variation, climate variation. He collaborated on projects of the World Meteorological Service. For the corresponding member of the Serbian Academy of Sciences and Arts, Vujevic was elected on November 14, 1950, and a regular on January 30,1958. In 1961, he was a member of the Presidency of the Academy of Sciences. He was declared an honorary citizen of the town of Hvar for his extensive work on the climate 
of the island of Hvar (243 pages), for which he used data from 60 years of observations of climatic elements.

\section{Writer of university textbooks}

The university textbooks Mathematical Geography (XVIII + 815 pages) and Meteorology (476 pages) are among the most important editions of the University of Belgrade in the first half of the 20th century. The work Climatologically Statistics (310 pages) is unique in our country. For an extensive and very comprehensive university textbook Fundamentals of Mathematical and Physical Geography, which in the first part deals with the problems of mathematical geography and geophysics, and in the second atmosphere and oceans, it was stated that it was printed among the first at the University of Belgrade after the First World War. Kingdoms of Serbs, Croats and Slovenes was written on the basis of a good knowledge of worldproven original literature and in its own way it contributed to the high level of teaching and, in its time, to the true aspirations of students and teachers of the University of Belgrade.

The textbook was an irreplaceable reading for students of many professions whose interest was not only in physical geography, in the broadest sense of the word, but also in meteorology, climatology, oceanography, cosmography and the Earth as a planet - a member of the solar system, orientation, determination of geographical coordinates, calculation of time) and its physical properties: mass, density, structure, magnetism, electricity (Rakićević,1998). The university textbookMeteorology, published by Prosveta from Belgrade, appeared in print in 1948 on 476 pages. It was the only one of its kind in Serbia and Yugoslavia at the time, and it is still quoted today. He contributed many times to the general introduction to the peculiarities of the atmosphere and pointed out the applicative importance of climatology and meteorology in a number of vital human activities (agriculture, traffic). Due to its lessons, messages and significance, in 1949 he received the First Prize of the then Government of Yugoslavia. Climatologically statistics is possibly one of the most unusual, but very important, university textbooks (Naučna knjiga, 1956). These are instructions for collecting and processing meteorological data and their numerical, graphical and cartographic representation. It abounds in the interpretation of standard methods of mathematical statistics, established probability theories, aspects of control, elements of periodicity of phenomena and processes, computer procedures, 
which... often from a very extensive material of meteorological observations can obtain a simple overview of climate change from which certain laws can be derived, to determine the connections and the influence of certain meteorological elements on a specific climatic phenomenon. This textbook is the result of a conscientious and dedicated effort of a teacher's nature, the will to instruct people who want to teach them in climatological work, and it has an exceptional necessity and practical significance. The concept of the textbook is based mainly on the author's many years of experience, and largely presents his original work (Rakićević, 1998). Pavle M. Vujević published scientific and professional articles in domestic and foreign journals in Serbian, German, French and English. Due to the inalienable scientific significance, lessons and messages, many views of Pavle M. Vujević, exhibited in numerous works and extensive books, are still quoted today, especially knowledge about bioclimate.

\section{Climate as the morphology of the atmosphere}

Pavle M. Vujevic was a man with many humane and hard-working human qualities, because of which he enjoyed great respect from students and associates, both in Serbia and abroad. He emphasized the importance of science and taught respect, respect, diligence, modesty, and perseverance. He emphasized the fact that almost everything on the planet Earth is based on numerous mutual relations, mergers and permeations, direct, indirect and feedback, evolution. He interpreted climate as the morphology of the atmosphere (Dukić, 1981) in great dependence on the circulation of the atmosphere, changes in the intensity of solar radiation, the distribution of the sea and land, i.e. degree of maritimeity and continentality. It has been noted in the literature that he was, and remains, a pioneer of microclimatology and an immortal researcher of prismatic air layers. In addition, he was the first to start measuring soil temperature at certain depths, which is extremely important for agro climatology. Respecting the climatic conditions, respecting the dialectical-materialist scientific method, he brought them into connection with geomorphology, that is. Relief features. He defined climate as the morphology of the atmosphere, in which the most important are various air masses, quickly changing and easily moving, where the existing relations between the sea and the land are of interest, which maintains the degree of continentality, that is, the degree of maritimeness. With the textbooks Meteorology and Climatologically Statistics, he contributed to the scientific and applied knowledge of the relevant sciences, important for agriculture, 
construction, traffic, weather forecast, i.e. the overall life of man and human society. Of special importance is the contribution he gave to the research of microclimatology, ie, research of ground layers of air and thermal regime of the soil at certain depths.

\section{Professor of encyclopedia}

Academician and university professor, one of the pillars of our science, Pavle M. Vujević reaches the national, European and world level. His basic scientific preoccupations concerned climatology, meteorology, mathematical geography, astronomy and hydrology. He was a climatologist who, from a pronounced physical-geographical, spatial, aspect, perceived and interpreted the peculiarities of time and climate. Significant journalistic activity of Pavle Vujević is also reflected in his work on Stanojević's National Encyclopedia (Book I-IV, Zagreb, 1928-1929), for which he wrote over 1200 determinants in the field of physical geography and geophysics. In addition, with his professionally popular works, he also greatly contributed to the affirmation of geography as a current, especially its share in the general educational and cultural enlightenment of the people. All the more so because there was something enlightening in his nature. A lot could be learned from him, as a scientist, professor, leader (Rakićević, 1998). In the eighth book of the Encyclopedia of Yugoslavia, published by the Yugoslav Lexicographic Institute in Zagreb, in 1957, on page 549, about Vujević, the text of his doctoral student, later professor of the Faculty of Geography and longtime president of the Serbian Geographical Society, Dušan Dukić (19232013), reads: Vujević, Pavle, geographer climatologist (Ruma, August 22, 1881 - Belgrade, November 17, 1966). He finished high school in Novi Sad, and studied at the University of Vienna, where he received his doctorate in 1904.

In March 1907, Vujević became an assistant professor of climatology and meteorology at the Faculty of Philosophy in Belgrade, and since then his intensive teaching and scientific work has begun. He participated in the Balkan Wars and the First World War, in 1919 he became an associate professor, in 1921 a full professor at the University of Belgrade, where he taught physical and mathematical geography, meteorology and climatology. For the climate monograph on the climate of Hvar (Belgrade, 1927-1932), in which he proved that the climate of Hvar is more suitable for treatment and rest than many famous Mediterranean beaches, he received a kind of recognition - he was elected honorary citizen of Hvar in 1931. In 1924-1948, 
Vujević was the director of the Meteorological Observatory in Belgrade, the organizer of the network of meteorological stations in Serbia, Macedonia and Montenegro, the head of the meteorology department at the Faculty of Science in Belgrade (1947-1955), the director of the Geographical Institute (1957). He was a corresponding member of many foreign geographical societies, a lifelong honorary president of the Serbian Geographical Society (1954), Vujević received multiple awards for his long-term teaching, scientificorganizational and scientific work (over 150 scientific articles). Many of his works have become classic works in river hydrology and microclimatology. Academician Pavle Vujević died in Belgrade on November 17, 1966.

In 1967, theSerbian Academy of Sciencesand Arts printed the Monument (Special Editions, Book CDXII, page 24), dedicated to the late academician Pavle M. Vujević. The speeches of academician Miodrag Tomić, academician Milisav Lutovac, professor of meteorology Marjan Čadež, professor of hydrology Dušan Dukić and president of the Serbian Meteorological Society, Milutin Radošević, were published at the commemorative gathering, which was held on March 25, 1967.

\section{Bibliography of Professor Pavle M. Vujevic}

Die Theise, eine potamologische Studie. Penck`s Geographische Abhandlungen VII/4, pp. 76, Leipzig, 1906.

Siedlungen der serbischen Länder. Geographische Zeitschrift, №. XII, pp. 12, Jahrgang, Leipzig, 1906.

Температуре тла у Београду. Глас Српске краљевске академије наука LXXIX, Први разред књ. 32, стр. 82, Београд, 1909.

Die Temperaturverhältnisse der untersten Luftschichten. Sitsungaberichte d. K. Akademie d. Wissenschafen Math. natw. Kl. 118, Abt. II a, pp. 48, Wien, 1909.

Die Temperaturverhältnisse der untersten Luftschichten. Meteorologische Zeitschrift, pp. 2, Braunschweig, 1910.

Über die Bodentemperaturen in Belgrad. Meteorologische Zeitschrift, pp. 12, Braunschweig, 1911.

Утицај околних мора на температурне прилике Балканског Полуострва. Гласник СГД, св. 1, стр. 14, Београд, 1912. 
Written word of Pavle M. Vujević

Спољна траговина Краљевине Србије. Гласник СГД, св. 1, стр. 2, Београд, 1912.

Српско географско друштво. Гласник СГД, св. 1, стр. 3, Београд, 1912.

Друга фотографска изложба Српског географског друштва, Гласник СГД, св. 1, стр. 6, Београд, 1912.

Die Temperaturen verschiedenartiger Oberflächen, Meteorologische Zeitschrift, pp. 6, Braunschweig, 1912.

Die Einflüsse der umliegenden Meere auf die Temperaturverhältnisse der Balkanhalbinsel. Geographische Jahresberichte aus Österreich, №. X, pp.18, Wien, 1913.

Über die Beschaffenheit der täglichen Temperaturkurve. Sitzungsberichte, K1. 123, pp. 34, Wien, 1914.

Копно и вода на Земљиној површини. Гласник СГД, св. 3.4, стр. 1, Београд, 1914.

Српско становништво у варошима Угарске. Гласник СГД, св. 3-4, стр. 5, Београд 1914.

Становништво у Угарским варошима. Гласник СГД, св. 3-4, стр. 1, Београд, 1914.

Статистички подаци о становништву Бугарске. Гласник СГД, св. 3-4, стр. 1, Београд, 1914.

Вароши и варошице у Вардарској Србији. Гласник СГД, св. 3-4, стр. 1, Београд, 1914.

Поглед на постанак, везе, значај и задатак климатологије. Гласник СГД, св. 5, стр. 14, Београд, 1921.

Број становника на земљи. Гласник СГД, св. 5, стр. 2, Београд, 1921.

Становништво Немачке. Гласник СГД, св. 5, стр. 2, Београд, 1921.

Александар Војејков. Гласник СГД, св. 5, стр. 1, Београд, 1921.

Претходни резултати пописа становништва у Краљевини Срба, Хрвата и Словенаца 31. јануара 1921. Гласник СГД, св. 5, стр. 16, Београд, 1921.

Подаци о становништву и његовим друштвеним приликама у Астроугарској Републици. Гласник СГД. св 6, Београд, 1921. 
Податци о површинама и становништву у Чехословачкој Републици према покрајинама и новим крајевима. Гласник СГД, св. 5, стр.2, Београд, 1921.

Вароши у Немачкој са више од 200.000 становника. Гласник СГД, св. 5, стр. 1, Београд, 1921.

Опште црте београдског поднебља. Споменица Симе Лозанића, стр. 16, Београд, 1922.

Цвијић као географ и професор. Нова Европа, бр. 7, стр. 6, Загреб, 1923.

Основи математичке и физичке географије (Математичка географија I део , Геофизика). Државна штампарија Краљевине Срба, Хрвата и Словенаца, стр. X+346, Београд, 1923.

Рад и значај Првог конгреса словенских географа. Гласник СГД, св. 10, Београд, 1924.

Хидрографија и клима Војводине. Војводина, Удружење југословенских инжењера и архитеката, Секција Нови Сад, стр. 21, Нови Сад, 1924.

Клима Краљевине Срба, Хрвата и Словенаца. Зборник радова посвећен Јовану Цвијићу поводом тридесетпетогодошњице научног рада од пријатеља и сарадника. Универзитет у Београду, Географско друштво, Географски институт Универзитета, стр. 21, Београд, 1924.

Претходни резултати пописа становништва у Краљевини Срба, Хрвата и Словенаца. Гласник СГД, св. 11, Београд, 1925.

Die klimate der geologischen Vorzeit (приказ рада В. Кепена и А. Вегенера). Гласник СГД, св. 11, Београд, 1925).

Основи математичке и физичке географије II део (Атмосфера, Океани). Државна штампарија Краљевине Срба, Хрвата и Словенаца, стр. 468, Београд, 1926.

Јован Цвијић. Дневни лист Политика, број 6727, 17. јануар, Београд, 1927.

Јован Цвијић као географ и професор. Дневни лист Правда, 19. јануар, Београд 1927.

Јован Цвијић као национални радник. Вардар, календар за 1928 годину, стр. 9, Београд.

Jovan Cvijić. Czasopismo geograficzne, tom V, zesz. 2-3, pp. 6, Lwóv, 1927. 
Stan geografiji w Królestwie Serbow, Chorwatów i Slowenców. Czasopismo geograficzne, tom V, zesz. 2-3, pp. 15, Lwów, 1927.

Инслација на средњем и јужном јадранском приморју. Гласник СГД, св. 13, стр. 7, Београд, 1927.

О географској подели и режиму киша у нашој земљи. Гласник Министарства пољопривреде и вода, год. V, бр. 20, стр. 33, Београд, 1927.

О географском положају и поднебљу Београда. Савремена општина, година II. бр-67, стр.7, Београд, 1927.

О поднебљу Хвара I део (Температура, Влажност ваздуха, Облачност). Гласник СГД, св. 13, стр. 45, Београд, 1927.

Курс астрономије, теорни део (приказ рада др Н. Ј. Цингера), Гласник СГД, св, 13, Београд, 1927.

О поднебљу Хвара II део (Магла, Атмосферски талози). Гласник СГД, св. 14, стр. 38, Београд, 1928.

О трајању сунчевог сјаја у Јужној Србији. Гласник Скопског научног друштва, св. 6, Одељење природних наука, св. 2, стр. 22, Скопље, 1928.

Јован Цвијић као научник и национални радник. Мала билиотека, Сарајево, 1928.

Јован Цвијић. Народна енциклопедија, књ. СХC, св. IV/8, Београд, 1928.

Метеорологја. Народна енциклопедија Српско-Хрватска-Словеначка, књ. 2, стр. 5, Библиографски звод Д. Д. Загреб, 1928.

Србија. Народна енциклопедија Српско-хрватско-словеначка, Библиографски завод Д. Д. стр. 8, Загреб, 1928.

Милан Недељковић. Народна енциклопедија Српско-хрватскословеначка, Библиографски завод, Д. Д, књ. 2, Загреб, 1928.

Sonnenscheindauer im mittleren und südlichen Küstenlande der Adria. Gerlands Beiträge zur Geophysik, Band XX, heft 3-4, pp. 3, Leipzig, 1928.

Klimatographie der ehemaligen ősterreichi scheb Küsrenlands (приказ рада Е. Биела), Гласник СГД, св. 14, Београд. 1928.

Die Temperaturrverhlt nise der Túrkei (приказ рада Pelegrin Zistkera). Гласник СГД, св. 14, стр. 5. Београд, 1928. 
Генерална дирекција вода. Извештај секције за испитивање реке Мораве о снимању реке Велике Мораве. Гласник СГД, св. 14, Београд, 1928.

Прослава стогодишњице Географског друштва у Берлину. Гласник СГД, св. 14, стр. 1, Београд, 1928.

Роалд Амундсен (некролог), Гласник СГД, св. 24, стр. Београд, 1928.

Едуард Бринер (некролог). Гласник СГД, св. 14, стр. 1, Београд, 1928.

Оти Норденшелд (некролог). Гласник СГД, св. 14, стр. 1, Београд, 1928.

О трајању сунчева сјаја у Јужној Србији. Гласник Скопског научног друштва, књ VI, св. 2, стр. 22, Скопље, 1929.

О поднебљу Хвара III део (Атмосферски притисак, Ветрови). Гласник ГД, св. 15, стр. 37, Београд, 1929.

О открићу Антарктика и Јужног пола. Наука и природа, година II, бр. 6, стр. 16, Београд, 1929.

Die Fortschritte der Länderkunde von Europa: Südslawien 1913-1928. Geographisches Jahrbuch No. XLIV, pp, 63, Leipzig, 1929.

Climat, Royaume de Yougoslavie Apercu géographique et etnographique. Beograd, pp. 19, 1930.

Hydrographie, Royaume de Yougoslavie Apercu géographiqe et etnographique. Belgrade, 1930.

Понебље Краљевине Југославије, географски и атнографски преглед. Штампарија Давидовић, Павловића и друга, стр. 18, Београд, 1930.

Hydrographie Royame de Yougoslavie. pp. 20, Beograd, 1930.

Хидрографија Краљевине Југославије. Београд, стр. 17, 1930.

Краљеина Југославија - Географски и етнографски прглед, Штампарија Давидовић, стр. 26, Београд, 1930.

Опис пута III конгреса словенских географа и етнографа у Краљевини Југославији 1930, Штамаија Давидивић, Београд, 1930.

O поднебљу Хвара IV део (Брзина ветра). Гласник ГД, св. 16, стр. 36, Београд, 1930.

Das Klima Dalmatines (приказ радаа Ервина Биела). Гласник ГД св. 16, стр. 1, Бепград, 1930. 
Дневни и годошњи период кише у Загребу (приказ рада Стјепана Шкерба), Гласним ГД, св. 16, стр. 1, Београд, 1930.

Хоризинтани удио аномалног магнетског поља у Хрватскоји Сковенији (приказ рада Јосипа Марковића), Гласник ГД св, 16, стр. 1, Беиград, 1930.

Климатична скица на Бъгария (приказ рада Т. Кирова), Гласник ГД, св. 16, стр. 1, Београд, 1930.

O поднебљу Хвара V део (Карактеристични ветрови). Гласник ГД, св. 17, стр. 46, Београд, 1931.

О поднебљу Скопске котлине. Гласник Скопског научног друштва, Одељење природних наука, св. 7, стр. 91, Скопље, 1931.

Documents historiques sur les variation de climat dans les territoires de Royaume de Yougoslavie et des contrées avoisinantes. Union Géographique Internationale, Comité National du Royaume de Yougoslavie, pp. 58, Paris, 1931.

Годишњи и дневни период облачности у Загребу (приказ рада J. Голдбера). Гласник СГД, св. 17, стр. 2. Београд, 1931.

Bura et maestral (prikaz rada Е. Benéventa). Гласник СГД, св. 17, стр. 1, Београд, 1931.

Zum Klima der Bjelašnica (приказ рада H. Renijera), Гласник СГД, св. 17, стр. 1, Београд, 1931.

Variation periodique du climat en Yougoslavie. Libraire Armand Colin, Paris.

О поднебљу Хвара VI део (Карактеристична годишња доба). Гласник ГД, св. 18, стр. 25, Београд, 1932.

Temperature v Potočki zijalki na Olševi (приказ рад С. Богнара). Гласник ГД, св 18, Београд, 1932).

Smeri vetrov na Slovenskem i njih letni tok (приказ рада O. Reya), Гласник ГД, св. 28, Београд, 1932.

Die klimate der Erde (приказ рада Хетнера Алфреда), Гласник ГД, св. 18, Београд, 1932.

Handbuch der Klimatologie von Julius von Hann (приказа рада Кнох Карла). Гласник СГД. св. 18, Београд, 1932. 
Поређење поднебља у Охридској и Битољско-прилепској котлини. Гласник ГД, св. 19, стр. 16, Београд, 1933.

Поднебље Београда. Београдске општинске новине, бр. 2, стр. 7, Београд, 1933.

Paralellele entre les climat des bassins d'Ohrid et de Bitolj-Prilep. Comptes Rendus du Congres International de Géographie, tome II, Premier fascicule, pp. 33, Paris, 1933.

Variations périodiques dy climat en Yiugislavie. Comptes Rendus du Cingras International de Géographie, tome II Premier fsscicule, pp 17, Paris, 1933.

Кретање ветрова у Јаша Томићу 1930-1932, св, 19, стр. 1, Београд, 1933.

Über die getwotter in Súbosteneuropa (приказ рада И. Рениера), Гласник св. 19, стр. 1, Београд, 1933.

Kisérlet Magyaeország klimatérképének szerkesztéséve a köppenféle klimabeosztás értelmében, Гласник ГД, св. 19, стр. 1, Београд, 1933.

Buda százeves hömérseklet közepei, Гласник ГД, св. 19, стр. 1, Београд, 1933.

Die Niederschlagsverhältnisse der Türkei, Гласник св. 19, стр. 1, Београд, 1933.

L'influence du relief du sol le climat dans les environs de la montagne Bjelašnica. Recueil de travaux dédié par la Siciété Géographique de Lwów, pp. 26, Lwów, 1934.

Утицај рељефа земљишта на поднебље у околини Бјелашнице. Гласник ГД, св. 20, стр. 20, Београд, 1934.

Дунав - хидрографски опис. Морнарички гласник, година II, св. 6, стр. 9, Земун, 1934.

Реке и језера Југославије. Морнарички гласник, година II, св. 6, стр. 9, Земун, 1934. Ветрови на Јадранском мору. Морнарички гласник, год. II, св. 1, стр. 9, Земун, 1934.

Hydrographie der jugoslawischen Gewässer. Verhandlungen d. Internationalen Vereinigung für theoretische und angewandte Limnologie, Band VII, pp. 21, Belgrad, 1935.

Dinarskogorski fén. Гласник ГД, св 21, Београд, 1935.

Odnošaji med padavinami in cikloni v Jugoslaviji, Гласник ГД, св. 21, Београд, 1935. 
Written word of Pavle M. Vujević

Navali hladnega on toplega zraka v Dravsko banovino. Гласник СГД, св. 21, Београд, 1935.

О степену континенталности места у Југославији. Гласник ГД, св. 22, стр. 13, Београд, 1936.

Sur le degré continentalité en Yougoslavie. Mélanges de géographie offerts par ses collégues et amis de l'étranger à M. Václav Švambera à l'occasion de son soixante dixiéme anniversaire, pp. 14, Praha, 1936.

Sur la classification des climats du point de vue général. Comptes Rendus du Congres International de Géographie, tome deuxueme: Travaux de la section II, pp. 6, Varsovie, 1936.

Variatione périodiques du climat de Yougoslave. Congres International de Géographie, tome deuxueme, travaux de la sectio 2, pp. 13, Varsovie, 1936.

Sur la durée d'insolation en Yougoslavie. Сборник на IV конгрес на Славјанските географи и етнографи, стр. 4, Софија, 1938.

Die Verteilung des Luftdruckes über Griechenland. Vierteljahrzeitschrift für Südosteuropa, heft 2, pp. 9, Leipzig, 1938.

Средње десетогодишње вредности главних климатских елемената у Београду за период 1891-1960. Београд, 1938.

Геополитички у физичко-географски приказ Војводине. Војводина, Историјско друштво, књ. 1, стр. 28, Нови Сад, 1939.

Подела атмосферског притиска у Грчкој. Хрватски географски гласник, Споменица у част професора Артура Гавација, бр. 8-9-10, стр. 7, Загреб, 1939.

Magyarország éghajlata. Гласник ГД, св, 35, Београд, 1939.

Густав Хелман (некролог), Гласник ГД, св. 26, Београд, 1940.

Метеорологија. Издавачко предузеће Просвета, стр. 476, Београд, 1948

Клима и хидрографија Југославије. Коларчев народни униврзитет, Књижица за народно просвећивање, бр. 55, стр. 27, Београд, 1948.

Връху някои основни фактори и проблеми относно климата на Бьлгария. Гласник СГД, св, 28, Београд, 1948.

Климатична скица на Беломорска Тракия и приморска Македония. Гласник СГД, св. 28, Београд, 1948. 
Клима и хидрографија Југославије. Географија ФНРЈ, Дописни народни универзитет, књига 4, стр. 29, Београд, 1949.

Албрехт Пенк (некролог). Гласник СГД, св. 30, бр. 2, Београд, 1950.

Meteorologiche Besonderheiten der Ägais. Гласник СГД, св. 30, бр. 2, стр. 1, Београд, 1950.

Хидролошке особине река у НР Србији. Хидротехничке мелиорације у НРС, Институт за водну привреду НР Србије, стр. 17, Београд, 1951.

Хидрографске прилике југословеснких вода. Информативни приручник о Југославији, Књ. I, св. 10-11, стр. 3, Београд, 1951.

Клима Македоније. Други конгрес на географите од ФНРЈ. Географско друштво Македоније, стр. 13, Скопље, 1952.

Монсуни. Земља и људи св. 2, стр. 15, СГД, Београд, 1952.

Поднебље ФНР Југославије. Архив за пољопривредне науке, год. VI, св. 12, стр. 43, Београд, 1953.

Продирање морских утицаја у унутрашњост Југославије. Трећи конгрес географа Југославије, Географско друштво Босне и Херцеговине, стр. 4, Сарајево, 1954.

Комбиновани климатски елементи. Весник Хидрометеоролошке службе ФНРЈ, година IV, бр. 1-2, стр. 5, Београд, 1955.

Разлика у висини летњих и јесењих падавина као мерило њиховог маритимитета односно континенталитета. 3борник радова САНУ, књ. 46, стр. 18, Београд, 1955.

Les caractéristiques climatiques de la côte Yougoslave. Congrés International d'Hydro-Climatisme et de Thalassothérapie, tome I, pp. 4, Opatija, 1956.

Corrélation entre les pressions barométriques et les précipitations en Yougoslavie. Scientific Proseedings of the International Association of Meteorology. Tenth General Assembly Roma, Published by Butterworths Scientific Publications, pp. 6, London, 1956.

Климатолошка статистика. Научна књига, стр. X + 300, Београд, 1956.

Живот и јавни рад Јована Цвијића. У спомен тридесетогодошњице смрти Јована Цвијића. Посебна издања САНУ, књ. CCLXXVI, Споменица, књ. 12, Географски институт Јован Цвијић, књ. 12, стр. 8, Београд, 1957. 
Комбиновани климатски елементи на тврђави Петроварадина. Зборник Матице српске за природне науке, св. 13, стр. 22, Нови Сад, 1957.

Температура бунарске воде на земљишту бивше Опсерваторије Велике школе у Београду. Зборник радова, књ. 13, стр. 29, Београд, 1957.

Моћ хлађења и моћ сушења на тврђави Петроварадина. Зборник Матице српске за природне науке, св. 14, стр. 58, Нови Сад, 1958.

Gradients et inversion des températures de $\mathrm{l}^{\prime}$ air dansquelques tangs de la République Populaire de Serbie, Гласник СГД, св. XXXVIII, бр. 1, стр. 2, Београд, 1958.

Живот и рад покојног др Милутина Миланковића. Весник, год. VII, б. 3-4, стр. 7, Београд, 1958.

Поднебље Црне Горе. Зборник радова Петог конгреса географа ФНРЈ, стр. 17, Цетиње, 1959.

Вештачки сателити Земље и Сунца и путање ракета са животињама. Земља и људи св. 9, стр. 14, СГД, 1959, Београд.

Пролози за биоклиматологију области Копаоника. Зборник радова Географског института Јован Цвијић САНУ, књ. 18, стр. 91, Београд, 1962.

Топлотне прилике Метеоролошке опсерваторијеу Београду. Глас Српске академије наука и уметности, CCLII, књ. 23, стр. 55, Београд, 1963.

Метеорологија, Србија. Енциклопедија Југославије, књ. 6, Југославенски лексикографски завод, Загреб, 1965.

Недељковић Милан. Енциклопедија Југославије, књ, 6, Загреб, 1965.

Утицај климатских фактора на вредности и расподелу метеоролошких елемената. Фонд Савезног хидрометеоролошког завода, стр. 35, Београд, 1965.

Средње десетогодишње вредности главних климатских елемената у Београду за период 1891-1960. Глас Српске академије наука и уметности, CCLXV, књ. 29, стр. 55, Београд, 1966.

Дунав - хидрографски опис. Земља и људи св. 17, СГД, Београд, 1967.

Life and public work of Jovan Cvijić. Cvijić and karst, Cvijić et karst, Serbian Academy of Science and Arts, Board on Karst and Speleology, Belgrade, 2005. 


\section{Conclusion}

Pavle M. Vujević belongs to the generation of scientists, university professors and academics who are among the founders of scientific and teaching work in Belgrade, in the first years after the founding of his university. He was educated and trained abroad, but he remained faithful to Serbia and in his own way contributed to the development of hydrology, climatology and meteorology as subjects and operational disciplines in the field. He published short notes, chronicles, statistics, obituaries, reviews of foreign literature, scientific articles, scientific monographs and university textbooks in domestic and foreign journals in Belgrade, Zemun, Zagreb, Novi Sad, Cetinje, Skopje, Sarajevo, Leipzig, Vienna, Paris, Prague, Warsaw, and Sofia. His works have been published in Serbian, German, French, English and Czech. The weather and events in Serbia, on the Balkan Peninsula and in Europe were not in his favor. He often created radio under very unfavorable conditions. In 85 years of his life, among other things, he had the First Balkan War, the Second Balkan War, the First World War, the Second World War, Serbia under the occupation of foreign powers, the formation of the Kingdom of Serbs, Croats and Slovenes and several changes of name, borders and political and social order. For more intensive scientific studies, he lacked data from specific meteorological observations, from a large number of stations in Serbia and on the Balkan Peninsula. It is known that in 1904 there were 83, and in 1914 only 11 meteorological stations in Serbia. Climate studies by Vujević were not an end in itself. He brought the climate into direct and indirect connection with man and human activity. When he defined the basic bioclimatic elements, drying power and cooling power, ie determined the elements of equivalent and equivalent-effective climate and their effect on the human body, he pointed out the importance of climatotherapy. When it comes to the influence of climate on the general life of man, the following sentences are often quoted today: Sunny days have a completely different influence on mood than cloudy and gloomy days. When the sky is clear, a person is not only happier, but also more enterprising and willing to work. In addition, there are significant differences in the nature of the talkative and enthusiastic Spaniards and Italians and the measured and cold-blooded British and Scandinavians. This is felt in literature, music, and folk art. Folk songs are ballads for northerners, and romances for southerners. 


\section{References}

Боривоје Ж. Милојевић: Поводом педесетогодишњице научног рада Павла М. Вујевића. Гласник Српског географског друштва, сb. XXXIV, бр. 2, Београд, 1954.

Љубица Вранешевић: Академик др Павле Вујевић. Зборник за природнре науке Матице српске, књ. 17, Нови Сад, 1959.

Душан Дукић: Живот и рад Павла Вујевића. Гласник Српског географског друштва, cb. XLVI, бр. 2, Београд, 1966.

Душан Дукић: Живот и рад Павла Вујевића. Земља и ьуди, сb. 17, Српско географско друштво, Беогрд, 1967.

Стеван М. Станковић: Српски природословици - Павле Вујевић. Природа, бр . 7, Хрватско природословно друштво, Загреб, 1975.

Душан Дукић: Павле Вујевић и Српско географско друштво. Гласник Српског географског друштва, сb. LXI, бр. 2, Београд, 1981.

Dušan Dukić: Pavle Vujević (1881-1966) Geographers. History of Geographical thought, vol. 5, Munsell Publishing Lim, London, 1981.

Љерка Опра: Павле Вујевић и хроника времена на Балкану. Часопис за историју науке Флогистон, бр. 5, Музеј науке и технике Српске академије наука и уметности, Београд, 1997.

Љерка Опра: Девет храстова. Републички хидрометеоролошки завод, Музеј науке и технике Српске академије наука и уметности, Завод за уџбенике и наставна средства, Београд, 1998.

Томислав Ракићевић: Павле Вујевић. Живот и дело српских научника, къ. IV, II одељење, Српска академија наука и уметности, Биографије и библиографије, Одбор за проучавање живота и рада научника у Србији и научника српског порекла, књ. 4, Београд, 1998.

Томислав Ракићевић: Академик Павле Вујевић - утемељивач савремене климатологије у Србији. Гласник Српског географског друштва, св. LXXVIII, бр. 2. Београд, 1998.

Стеван М. Станковић: Тиса академика Павла Вујевића. Футура, књ. 3, Агенција Ваљевац, Београд, 1998.

Стеван М. Станковић: Павле Вујевић 1881-1966. Географски кампови. Креативни и даровити Србије, Београд, 2001. 
Стеван М. Станковић: Екологја академика Павла Вујевића. Зборник радова Еколошка истина, Завод за здравствену заштиту из Зајечара, Технчки факултет у Бору, Универзитета из Београда, Доњи Милановац, 2001.

Стеван М. Станковић: Паһле Вујевић - климатолог за сва времена. Часопис Геа, бр. 9, Департман за географију, туризам и хотелијерство Природно-математичког факултета, Универзитета у Новом Саду, Нови Сад, 2003.

Стеван М. Станковић: Цвијићева географска школа и юени академици. Научна монографија Географско образовање, наука и пракса, развој, стање и перспективе, Географски факултет Универзитета у Београду, Београд, 2014.

Стеван М. Станковић: Павле Вујевић - време, клима и човек. Зборник радова Планска и нормативна заштита простора и животне средине, Асоцијација просторних планера Србије, Географски факултет Универзитета у Београду, Београд, 2015.

Милован Пецељ и Стеван М. Станковић: Географи у Векликом рату. Географски факултет Универзитета у Београду, Београд, 2019. 